полі соціальної компетентності особистості [2].

Рефлексивний компонент: самоаналіз соціальної діяльності, саморозвиток особистості. Властивістю компонента $\epsilon$ здатність до осмислення основ своєї діяльності, в ході якого здійснюється оцінка і переоцінка своїх здібностей, особистих досягнень; свідомий контроль результатів дій, аналіз реальних педагогічних ситуацій. Містить здатність до саморозвитку особистості.

Отже, аналіз психолого-педагогічної літератури засвідчує, що теорія, принципи та методика формування соціальних знань, умінь і навичок потребує грунтовних досліджень на різних структурних рівнях. Застосування компетентнісного підходу, інтерактивних технологій навчання й діяльності студентів у сучасному соціальному середовищі передбачають особистісно-діяльнісну спрямованість навчання.

Соціальна компетентність формується завдяки структурованим ключовим компетенціям (когнітивна, інтерактивна, операційна, імплементаційна, рефлексивна), кожна 3 яких наповнена визначеним переліком здібностей суб'єкта навчального процесу. Описано мотиваційно-особистісний, партисипативно-діяльнісний, імплементаційно-управлінський та рефлексивний компонентні складники дидактичної моделі формування соціальної компетентності студентів.

Відкритими для подальших розвідок залишаються питання ефективного застосування інтерактивних технологій навчання у процесі формування соціальної компетентності студентів.

\title{
Література
}

1. Бойчук П. М. Модель формування соціальної компетентності студентів педагогічних коледжів / М. П. Бойчук, Н. В. Борбич // Соціальна педагогіка: теорія і практика. - 2013. - № 1. - С. 35-43. 2. Зарубінська І. Б. Проблема діагностики соціальної компетентності студентів вищих навчальних закладів / І. Б. Зарубінська // Інформаційні технології й засоби навчання. - 2009. - № 5 (3). - Режим доступу до журналу: www.ime.edu-ua.net 3. Компетентнісний підхід у сучасній освіті: світовий досвід та українські перспективи: Бібліотека освітньої політики / за заг. ред. О. В. Овчарук. - К. : К.І.С., 2004. - 112 с. 4. Остапенко С. Компонентна структура соціальної компетентності студентів філологічних спеціальностей / С. Остапенко // Вища школа. Спецвипуск № 8. - Ч. 1. - С. 187-194. 5. Слєпкань 3. І. Наукові засади педагогічного процесу у вищій школі: [навч. посіб.] / 3. І. Слєпкань. - К. : Вища школа, 2005. - 239 с. 5. Стратегії модернізації змісту вищої освіти: матеріали для розробки документів 3 оновлення загальної освіти. - К. : ТОВ «Світ книги», 2001.95 c. 6. Rychen D.C. et al. Key Competencies for Successful Life and Well-Functioning Society. - OECD: Hogrefe and Huber, 2003. - 224 p.

УДК 371.315.6: 372.4

Олена Ковшар

\section{ОСВІТА ЯК ПЕДАГОГІЧНА КАТЕГОРІЯ В КОНТЕКСТІ ГЛОБАЛІЗАЦЙ І ВИКЛИКІВ ЧАСУ}

Ковшар О. В. Освіта як педагогічна категорія в контексті глобалізацій і викликів часу.

У статті автор пояснює феномен «освіта», з позицій якого можна максимально сприяти соціалізації людини, ii оптимальній адаптації до життя в суспільстві; визначає важливість глобалізації та модернізації сучасної освіти, акцентує увагу на принципах, функціях та підходах іiі організації.

Ключові слова: освіта, освіта як процес, глобалізація освіти, функції сучасної 
освіти, принципи освіти, самоорганізація, взаємодія.

Ковшар Е. В. Образование как педагогическая категория в контексте глобализации и требований времени.

В статье автор объясняет феномен «образование», с позиций которого можно максимально способствовать социализации человека, его оптимальной адаптации к жизни в обществе, определяет важность глобализации и модернизации современного образования, акцентирует внимание на принципах, функциях и подходах его организации.

Ключевые слова: образование, образование как процесс, глобализация образования, функции современного образования, принципы образования, самоорганизация, взаимодействие.

Kovshar O. V. Education as a pedagogic category in context of globalization and call of the time

The author explains the phenomenon of education from the standpoint of which one can best contribute to socialization of people, his or her optimal adaptation to social life. The author also determines the importance of globalization and modernization of modern education. The article focuses on the principles functions and approaches of its organization.

Key words: education, education as a process, globalization of education, features of modern education, principles of education, self-organization, interaction.

Сучасний стан розвитку теорії і практики освіти характеризується напруженим пошуком шляхів актуального й прогнозного (випереджувального) реагування на виклики часу. Високий динамізм змін, глобалізаційні процеси, непередбачуваність майбутнього, кризи, інтенсивне зростання високотехнологічних виробництв i комунікацій, людської географічної й економічної мобільності - усе це позначається на якості життя у кожній країні.

Ключовими, сутнісними характеристиками нинішньої й майбутньої освіти $є$ людиноцентризм, демократизація, інноваційність, безперервність, інформатизація й інші [1, с. 10-11].

В. Кремень зауважує, що до найважливіших світових тенденцій, що визначають зовнішні впливи на розвиток освіти, належить усебічна глобалізація освіти. Передусім активно формуються інноваційні утворення «світовий освітній простір», «європейський освітній простір», «світові освітні мережі». Різні рівні інтеграції освітніх, наукових, педагогічних, урядових, громадських організацій створюють небачені можливості задля їх співпраці, взаємодії в умовах інтерналізації різних галузей життя суспільств. Відбувається глобалізація навчальної, дослідницької, інноваційної діяльності шляхом формування нових систем дистанційного навчання і дослідницьких мереж, які діють у світі незалежно від географічних та політичних кордонів [3, с. 3-5].

У контексті глобалізаційних викликів освіту можна розглядати як надання споживачам певних освітніх послуг, а отже, освіта стає товаром, що задовольняє новітні потреби і водночас комерціалізується, перетворюючись на предмет бізнесу.

Освіта, віддзеркалюючи соціально-економічні запити, стає вагомим ресурсом у конкуруючих ринкових суспільствах, які пришвидшують інноваційний поступ. Тому сучасна людина у молодшому і зрілому віці об'єктивно змушена бути мобільнішою, гнучкішою, інформованішою, а також критично і творчо мислячою, громадянсько 
активною і відповідальною, а відтак мотивованою до свого розвитку, навчання, освіти.

Особливий виклик це становить для нашої країни, акцентує В. Кремень, країна, яка, адаптуючись до загальносвітових процесів, утверджує свою державність, незалежність, національну єдність, нові суспільні відносини, аби виступати рівноправним суб'єктом світотворення заради людського благополуччя. Маючи багаті національні традиції і напрацьовані останніми роками методологічні орієнтири щодо розвитку освіти (пріоритет загальнодержавної суспільної підтримки освіти, переорієнтація на людиноцентристський характер освіти, навчання, виховання, розвиток гармонійної, гуманної, соціально відповідальної особистості тощо). Українська держава відшукує оптимальні шляхи входження до загальноцивілізаційного, включаючи освітній, рух зі збереженням і примноженням своїх кращих національних здобутків. Побудова сучасної, одночасно національно прийнятої системи сприятиме розв'язанню і багатьох внутрішньодержавних проблем людського розвитку [1, с. 10].

У контексті глобалізаційних тенденцій і сучасних викликів пріоритетне завдання української освіти - професійніше готувати людину до життя в інформаційному суспільстві, суспільстві знань та інновацій. Уходження світу до науковоінформаційного типу прогресу зумовлює необхідність формування людини 3 інноваційним мисленням, інноваційною культурою, здатністю до інноваційної діяльності.

У дослідженні розглянемо освіту як систему, глобальну цінність, засіб модернізації та пізнання світового життя людини, як один із важливих шляхів розвитку i засобів формування інтелектуального потенціалу народу i окремої особистості.

Термін «освіта» в науково-педагогічній літературі виник у кінці XVIII сторіччя задля позначення формувально-виховного впливу навчання на особистість, проте воно не мало конкретного термінологічного сенсу і вживалось як синонім до слова «виховання». Так, Й. Песталоцці використовував цей термін у значенні «формування образу» [4, с. 67], пізніше для позначення всього навчально-виховного процесу. I тільки в другій половині XIX ст. феномен «освіта» набув свого термінологічного значення, при цьому, спочатку його пов'язували 3 навчанням, яке впливає на формування особистості.

У словникових джерелах «освіта» визначається як: «результат засвоєння систематизованих знань, умінь і навичок; необхідна умова підготовки людини до життя і праці [3, с. 351]; «сукупність знань, здобутих у навчанні» [3, с. 138]; результат процесу навчання, що виражається у системі знань, умінь і навичок, які формуються у процесі навчання, а також процес виховання, розвитку і саморозвитку, впливу, тобто процес формування особистості людини, при цьому головним $\epsilon$ не обсяг знань, а поєднання їх з особистісними якостями людини, вміння самостійно використовувати здобуті знання» [3, с. 373]. Як бачимо, дані твердження спрямовують поняття «освіта» тільки на кінцевий результат.

I. Харламов освіту трактує як «процес i результат оволодіння знаннями, вміннями, навичками, ... розвиток світогляду, ідейно-політичних поглядів і моральності, творчих здібностей і задатків» [5, с. 101], А. Бодаков «освіту» розглядає як «необхідну умову підготовки людини до життя і праці» [5, с. 586].

А. Хуторський зазначає, що освіту можна розуміти 3 таких позицій:

- передавання попередніми поколіннями наступним поколінням соціально значущого досвіду; 
- процес прогресивних змін особистості;

- організована взаємодія учня 3 довкіллям і самим собою [1, с. 49].

Найбільш повне визначення «освіти» подає С. Гончаренко, який розглядає іiі як процес i результат засвоєння особистістю певної системи наукових «знань, практичних умінь і навичок і пов'язаного з ними того чи того рівня розвитку іiі розумово-пізнавальної і творчої діяльності, а також морально-естетичної культури, які у своїй сукупності визначають соціальне обличчя й індивідуальну своєрідність цієї особистості. Це одна 3 найширших педагогічних категорій, яка має цілісну, поліфункціональну та полісмислову структуру» [1, с. 614]. С. Гончаренко виокремлює три функції освіти: людинотворчу - забезпечення певного рівня знань, грамотності; стану емоційно-вольової сфери, поведінкових орієнтацій, готовності до виконання різних соціальних ролей, видів діяльності тощо; технологічну - забезпечення «бази життя»; формування навичок і вмінь трудової, громадської, господарської, професійної діяльності; гуманістичну - виховання людей в дусі миру, високої моральності, культури, розуміння пріоритетів загальнолюдських цінностей (життя, праці, самої людини, природи тощо) [1, с. 615]. Ці функції органічно поєднуються 3 функціями навчання: освітньою, розвивальною, виховною.

По-різному визначають поняття «освіта» сучасні науковці М. Данилов, Б. Ссипов, І. Підласий та ін., а саме: «володіння системою знань, умінь і навичок; необхідна умова підготовки людини до життя, праці, формування наукового світогляду, розвиток пізнавальних сил і здібностей. Основний шлях здобування освіти - навчання» [6, с. 37]; «це обсяг систематизованих знань, умінь і навичок, способів мислення, якими оволодів той, кого навчали» [6, с. 25].

С. Гессен пов'язує освіту 3 культурою: «освіта - це не що інше як культура індивіда... скільки культурних цінностей, стільки і видів освіти» [6, с. 35].

Є. Бондаревська пов'язує освіту 3 цінностями, «освіта - це духовне обличчя людини, яке формується під впливом моральних і духовних цінностей» [1, с. 36].

Отже, освіта означає одночасно і соціальне явище, і педагогічний процес.

Освіту як процес досліджували такі науковці, як: В. Гершунський, Л. Занков та ін. Освіта як процес становить цілісну єдність навчання, виховання, розвитку, саморозвитку особистості; збереження культурних норм 3 орієнтацією на майбутній стан культури; створення умов для повноцінної реалізації внутрішнього потенціалу індивіда і його становлення як інтегрованого члена суспільства, виконуючи функцію наступності поколінь [1, с. 615]. Б. Гершунський уважає, що освіта як процес за своєю сутністю $є$ ні що інше, як процес руху від цілей до результату, процес суб'єктоб'єктної і суб'єкт-суб'єктної взаємодії педагогів і учнів, за яким той, хто навчається (дитина, учень, студент, слухач), чим більше виявляє активну, глибоку і всебічну участь у процесі навчання й учіння, виховання й саморозвитку перетворюється 3 достатньо пасивного об'єкта діяльності педагога на повноправного співучасника, тобто в суб'єкт педагогічної взаємодії (спілкування, комунікації) не тільки 3 педагогом, але й з іншими учнями [1, с. 99].

3 погляду класичної дидактики категорія «освіта» характеризується такими принципами, як: науковість, систематичність і послідовність. Керуючись ними, зазначає В. Краєвський, зміст освіти має бути суворо науковим, об'єктивно відображати сучасний стан відповідної галузі наукового знання 3 урахуванням тенденцій та перспектив розвитку. Знання, вміння і навички повинні формуватися в певному порядку: кожен елемент навчального матеріалу логічно повинен бути пов'язаний 3 іншими, наступне спирається на попереднє i готує до засвоєння нового [6, с. 46]. 
XXI ст. висуває нові вимоги до освіти, надає нові можливості для освітньої діяльності. Стан освіти в державі є показником якості життя суспільства, а тому в багатьох економічно розвинутих країнах саме держава є головним суб'єктом, який утримує систему освіти і визначає стратегічні напрями іiі модернізації. Сучасна цивілізація відчуває нагальну необхідність у створенні глобальної системи освіти, яка органічно включала б у себе локальні, регіональні і національні системи освіти при збереженні їх унікального етнокультурного ядра. Кожне суспільство відтворює себе через систему освіти, транслюючи наступному поколінню ті знання, уміння, навички, які надають змогу молодій людині включатися до структур суспільства, адаптуватися до їх змін, жити у суспільстві, реалізовувати себе як в особистісному, так і в професійному напрямах. 3 іншого боку, цивілізаційні тенденції розвитку, на думку В. Кременя, висувають нові вимоги перед людиною, а отже, і перед освітою, що відіграє вирішальну роль у становленні кожної особистості [3, с. 3]. Система освіти стала об'єктом вивчення як зарубіжних (С. Ароновіц, У. Бек, П. Бурдьє, П. Друкер, Х. Жирокс, К. Манхейм та ін.), так і вітчизняних (В. Бакіров, Г. Климова, К. Астахова, Є. Подольська, J. Півнева та ін.) дослідників, які зазначали, що система освіти створює можливості розвивати особистість у двох основних напрямах: 1) розвиток соціально значимих якостей: формування інтелектуального, морального і ресурсного потенціалу суспільства і держави; сприяння політичному, економічному і культурнотехнологічному розвитку суспільства; 2) самої особистості, суспільства і держави; підготовка людини до успішної й безпечної перетворювальної діяльності в сучасному соціумі.

Аналізу функцій сучасної освіти приділено досить багато уваги такими українськими педагогами, як: Ю. Зіньковський, 3. Курлянд, Г. Мірських, Г. Семенова, В. Тюріна, Р. Хмелюк та ін. Філософські інтерпретації функцій освіти з урахуванням сучасної ситуації представлені у працях В. Андрющенка, Т. Воропай, В. Кременя, I. Карпенка та інших учених. Бурхливі зміни сучасного життя потребують розглядати сьогодні освіту і як соціокультурний феномен,що виконує соціокультурні функції. Аналізуючи функції освіти, наприклад, Л. Коган виокремлює такі: освітні (передання знань, умінь, навичок, культурних цінностей); виховні (формування ціннісних орієнтацій у процесі виховання і навчання); ціннісно-орієнтаційній; розвивальні (формування пізнавальних психічних процесів і властивостей особистості, логічних операцій, пізнавальної активності, інтересів, здібностей) - людинотворчій; функції соціалізації (набуття досвіду спільної діяльності, оволодіння системою суспільних відносин і соціально прийнятної поведінки) - адаптаційній та ідеологічній функціям освіти [5, с. 112-114].

Характеризуючи категорію «освіта» в контексті глобалізації, необхідно зупинитись на характеристики їі принципів.

Одним із принципів функціонування i розвитку освіти $\epsilon$ іiі «культуродоцільність». За цим принципом освіта розглядається насамперед як соціальний інститут 3 функцією духовного відродження культури людини в суспільстві. Це означає навчання в контексті культури, орієнтацію освіти на характер і цінність культури, на засвоєння iii досягнень та іiі відродження, на засвоєння соціокультурних норм і залучення людини до їх подальшого розвитку.

У сучасному суспільстві свою ефективність підтвердила неінституціональна модель освіти [5, с. 100-102], що орієнтується на іiі організацію поза соціальними інститутами, зокрема освітніми. Це освіта «на природі», в умовах паралельних шкіл (радіо, телебачення, преса, які систематично готують спеціальні освітньо-виховні програми), за допомогою системи Інтернет, «відкритих університетів», дистанційного 
навчання і т. п. У контексті реалізації неінституціональної моделі освіти особливої уваги заслуговує позашкільна освіта 3 різних напрямів: художньо-естетичного, туристсько-краєзнавчого, еколого-натуралістичного, науково-технічного, дослідницько-експериментального, фізкультурно-спортивного, військовопатріотичного та ін. Така розгалужена система позашкільних установ створює додаткові можливості для духовного, інтелектуального і фізичного розвитку дітей та підлітків. Освіта розглядається як практика соціалізації людини і спадкоємності поколінь, вона $\epsilon$ механізмом формування суспільного і духовного життя людини i сферою масового духовного виробництва.

Головними підходами в аналізі педагогічної категорії «освіта» необхідно виокремити гуманістичний, діяльнісний, системний та цілісний. Дані підходи через змістовий аспект освіти пов'язані із проблемами соціалізації особистості, ціннісними орієнтаціями суспільства, особистості та освіти, збереженням, відтворенням і розвитком культури.

В. Краєвський переконливо доводить необхідність гуманістичної орієнтації як головного принципу освіти. Мається на увазі врахування індивідуальних особливостей особистості, спрямована освітнього процесу на можливий повний розвиток тих здібностей особистості, які потрібні їй і суспільству, на залучення до активної участі в житті, поєднання буття індивідуума 3 культурою. Такий підхід грунтується на принципах розвивального та виховуючого навчання, а також доступності, свідомості і активності навчання.

3 погляду діяльнісного підходу, який розглядає навчання як діяльність, весь зміст отримання освіти складається з чотирьох елементів:

- досвіду пізнавальної діяльності, зафіксованим у вигляді їі результатів - знань;

- досвіду здійснення відомих способів діяльності, тобто вмінь діяти за зразком;

- досвіду творчої діяльності, тобто готовності приймати нестандартні рішення у проблемних ситуаціях;

- досвіду здійснення емоційно-ціннісних стосунків.

Ці елементи пов'язані між собою таким чином, що кожен попередній служить передумовою для переходу до наступного.

3 погляду системного підходу, освіта - це цілісна система. Це означає, що на рівні освіти індивідуальні дії, зв'язки і взаємовідносини утворюють нову системну якість як особливий якісний стан, що не можна розглядати як просту сукупність елементів. Таким чином, категорія «освіта» характеризується цілісністю, взаємозв'язком і взаємодією елементів, а також наявністю системоутворюючих стрижнів.

Важливість вивчення освіти як цілісного соціального феномена в сукупності всіх його соціальних характеристик і аспектів створює цілісне уявлення про освіту. Саме поняття «цілісність» надає змогу проникнути в сутність освіти як системи, виявити іiі певну стійкість, органічний взаємозв'язок іiі частин, ऑiі внутрішню єдність. Як фундаментальна характеристика системи цілісність водночас $\epsilon$ критерієм іiі розвиненості.

Категорія «освіта» будується також на базі поєднання новітніх природничонаукових і гуманітарних знань, діалогу двох культур. Це зумовлено більш глибоким осмисленням зв'язків між дисциплінами, інтеграція яких забезпечує фундамент підготовки особистості до життя. Взаємозв'язок навчальних предметів, об'єднання (в сенсі змісту навчання) окремих навчальних дисциплін між собою мають метою створення у свідомості людини цілісної картини, яка слугує науковою основою його наступній практичній діяльності. 
Практика розвинутих країн показує, що в сучасному світі наука й освіта все більше $є$ головними структурними чинниками сучасної економіки.

Людські особистісні якості в сучасних умовах стають частиною професійного інструментарію. Саме тому необхідні суттєві зміни в теорії і практиці освіти, модернізації іiі на гуманістичній основі. Найважливішим підгрунтям освітнього процесу, його вихідним пунктом, своєрідним початком відліку має стати осмислення особистості, шляхів іiі розвитку і перетворення на теренах світової і національної культури. Адже освіта $\epsilon$ процесом долучення людини до культури і водночас результатом інтеріоризації культури, включення іiі у світ людської суб'єктивності як цілеспрямований процес виховання i навчання в інтересах людини, суспільства держави: саме в такій послідовності пріоритетів за сучасних умов культурологічна парадигма набуває форми культуроцентристського підходу до конкретної освітньої діяльності в їі змістовому і процесуальному аспектах.

Постіндустріальна культура підкреслює унікальність людини іiі інтелект і творчий потенціал стають основною продуктивною силою суспільства, що означає посилення ролі людського чинника, особливо таких якостей людини, як іï самобутність і самоцінність. Саморозвиток і самореалізація в культурі стають важливою суспільною цінністю, а формування здатності до саморозвитку i самореалізації, творчості, самовдосконалення i навчання впродовж життя важливими завданнями педагогіки постіндустріалізму.

Педагогіка постіндустріального світу (на відміну від педагогіки індустріального суспільства) спрямована на розвиток особистості в усіх багатоаспектних вимірах його прояву. Саме зрушення в динамічних, характеристиках розвитку особистості повинні визначати ефективність педагогічного впливу. Така педагогіка значно більше, ніж педагогіка індустріального суспільства, має грунтуватися на законах вікової та педагогічної психології. Оскільки особистість виховується особистістю, ефективність педагогічного впливу педагога постіндустріального суспільства значною мірою визначається моральними та духовними цінностями самого педагога, філософією його світогляду і погляду на світ. Негативним явищам, які несе 3 собою глобальне, інформаційне суспільство, може протистояти тільки особистість педагога - духовного й морального, філософія якого наповнена дитиноцентризмом, людяністю, захопленістю своєю справою.

Освіта в постіндустріальному суспільстві служить людині соціальним і професійним, захистом, надає змогу швидко адаптуватися до життєвих змін, стати самодостатньою особистістю, адже, розвиваючи розум і душевні сили особистості, вона допомагає замислитися не тільки над вирішенням особистісних і професійних проблем, а й зрозуміти ті перетворення, які відбуваються в суспільстві, стати їх активним учасником.

Цивілізаційні тенденції розвитку сучасного суспільства висувають нові вимоги перед людиною, а отже, і перед освітою, яка відіграє вирішальну роль у становленні кожної особистості. В силу цих тенденцій наука як сфера, що продукує нові знання, i освіта, яка олюднює знання, робить їх дієвими, діяльнісними, об'єктивно висуваючи до числа головних пріоритетів будь-якого суспільства, що претендує на конкурентоспроможність у сучасному світі. Це вимагає від країни, яка намагається бути конкурентоспроможною, по-перше, забезпечити пріоритетність освіти і науки i, по-друге, чітко визначити нові освітні завдання і рішуче та наполегливо взятися за їх реалізацію. Освіта повинна підготувати людину до нових умов життя і діяльності.

Людина у XXI столітті - це людина, яка постійно навчається. Людина, для якої отримання знань стає сутнісною рисою способу життя. Таку людину має формувати 
вже школа, а створити умови для безперервної освіти впродовж життя повинні суспільство і держава.

Аналізуючи категорію освіти в сучасному суспільстві, зазначимо, що визначення мети освіти на сучасному етапі полягає у всебічному розвитку людини як особистості й найвищої цінності суспільства, у збагаченні на цій основі інтелектуального, творчого, культурного потенціалу народу, підвищення його освітнього рівня, а також у забезпеченні народного господарства кваліфікованими фахівцями.

Модернізація сучасної освіти виявляється у пошуку нових шляхів розвитку освітніх систем; розробці й експериментальній перевірці моделей випереджувального розвитку навчальних закладів відповідно до розвитку суспільства; знаходженні рівноваги, оптимального співвідношення між «ринковістю» освіти і іiі головним завданням - навчанням, вихованням, розвитком особистості, підготовкою ії до життя в сучасному суспільстві, які неможливо реалізовувати лише за ринковими критеріями.

Зазначимо, що на розвиток та модернізацію системи освіти в сучасних умовах впливають такі чотири взаємопов'язані чинники: швидкозмінність і швидкоплинність процесів суспільного розвитку; соціально-економічні трансформації в суспільстві, що зумовили появу принципово нового для нашої економіки і соціального буття явища ринку праці; процеси глобалізації, які відгукнулися інтеграційними тенденціями в світі; інформаційний «вибух» у суспільстві, зумовлений появою нових інформаційних технологій і мультимедіа. Система освіти, виконуючи свою гуманістичну місію, має підготувати молоду людину до життя в сучасному відкритому світі. Тому розвиток $\mathrm{i}$ функціонування освіти зумовлені всіма чинниками й умовами існування суспільства: економічними, політичними, соціальними, культурними тощо.

Отже, людський розвиток, розвиток особистості, розвиток суспільства визначають саме зміст педагогічної категорії «освіта».

\section{Література}

1. Біла книга національної освіти України / за ред. В. Г. Кременя. - К. : ТОВ «Інформаційні системи», 2010. - 643 с. 2. Кремень В. Ключові завдання : утвердження пріоритетності і модернізація освіти / В. Кремень // Дошк. виховання. 2001. - № 11. - С. 5. 3. Педагогіка / під. ред. М. Д. Ярмаченка. - К. : Вища школа, 1986. - 543 с. 4. Песталоцці Й. Вибрані твори/ За ред. М. І. Гордієвского,
А. Г. Готалова-Готріба і
В. О. Чудновцева. -
Одеса,
1928. -
C. 67.

5. Степанова Т. М. Трансформації змісту передшкільної освіти в історії розвитку вітчизняної дошкільної педагогіки (кінець XIX-XX століття): [монографія]/ Т. М. Степанова. - К. : Видавничий Дім «Слово», 2011. - 424 с. 6. Харламов И.Ф. Педагогика / И. Ф. Харламов. - Минск, 1979. - 101 с.

\section{ОСНОВНІ ПЕРЕДУМОВИ ЕКОНОМІЧНОЇ ОСВІТИ У ШКОЛАХ ТЕХНОЛОГІЧНОГО ПРОФІЛЮ НАВЧАННЯ}

Кулішов В. С. Основні передумови економічної освіти у школах технологічного профілю навчання.

У статті здійснено спробу розкрити основні передумови й обгрунтувати актуальність створення системи економічної освіти i виховання у школах 3 технологічним профілем навчання.

Ключові слова: економічна освіта, проектно-технологічна діяльність учнів, сталий розвиток, синергетика, профільна економічна підготовка. 